\title{
CERITA RAKYAT INDRAGIRI \\ SEBAGAI BAHAN PENGAJARAN SASTRA DI SEKOLAH DASAR DALAM UPAYA PEMBENTUKAN KARAKTER ANAK
}

\author{
(Indragiri Folklore as Teaching Materials In Elementary School \\ In Order To Build Students' Character)
}

\author{
Marlina \\ Balai Bahasa Riau \\ Jalan Binawidya, Kampus UNRI, Panam, Pekanbaru, Riau, Indonesia \\ Posel: marlinabbpku@gmail.com
}

\begin{abstract}
Abstrak: Penelitian ini membahas tiga buah cerita rakyat Indragiri sebagai bahan pengajaran sastra di sekolah dasar dalam upaya pembentukan karakter anak didik. Tujuan penelitian ini adalah untuk mengenalkan budaya dan tradisi lisan melalui sastra dalam upaya membentuk karakter anak. Jenis penelitian ini adalah deskriptif analisis. Ketiga cerita rakyat dideskripsikan dan dinalisis karakterkarakter baik yang terdapat di dalam cerita tersebut yang bisa dicontoh dan diteladani oleh anak. Data dianalisis melalui pendekatan moral. Hasil penelitian menunjukkan bahwa kedua cerita rakyat Indragiri tersebut mengandung karakter baik seperti karakter relegius, bertanggung jawab, mandiri, kerja keras, menghargai, santun, dan kasih sayang. Karakter ini bisa dijadikan sebagai contoh dan teladan bagi anak. Dengan demikian penelitian ini menyimpulkan bahwa ketiga cerita rakyat Indragiri tersebut dapat dijadikan sebagai bahan ajar pembelajaran sastra di tingkat sekolah dasar dalam upaya pembentukan karakter anak.
\end{abstract}

Kata Kunci: cerita rakyat, bahan ajar, pembentuk karakter anak

Abstract: This study discusses three Indragiri folklores as literary teaching materials in elementary school in the effort to build students character. The purpose of this study is to introduce culture and oral tradition through literature in order to build the character of children. The type of this research is descriptive analysis. The three folktales are described and the good characters contained in the story that can be imitated and emulated by children is analyzed. The data were analyzed by applying moral approach. The result shows that the three Indragiri folklores contain good characters that can be imitated and emulated by children. Therefore, base on this study, it can be concluded that folklore can be used as a teaching material for literary learning at the elementary level in order to build children's character.

Keywords: folklore, teaching materials, building children's character

\section{PENDAHULUAN}

Pengajaran sastra di sekolah-sekolah tidak memperlihatkan adanya kebijakan dasar hendak mengakrabkan kesusastraan daerah kepada para anak didik. Pelajaran sastra hanya merupakan bagian kecil dari mata pelajaran bahasa. Pelajaran sastra terbatas pada uraian definisi-definisi teori sastra. Perkenalan terhadap karya sastra hanya berupa penapisan struktural karya-karya sastra tulis dengan petikan-petikan pendek saja dari suatu karya sastra, yang seringkali tidak memperhatikan mutunya.

Secara umum, dunia pendidikan kita mengalami semacam "cultural inferiority complex" rasa rendah diri akibat pengalaman dijajah. Ada anggapan bahwa kebudayaan nenek-moyang sendiri merupakan sesuatu yang beku, terbelakang, 
tak sesuai dengan zaman. Segala sesuatu yang bersifat tradisional itu terbelakang, primitif dan harus ditinggalkan. Sebaliknya kebudayaan 'tuan penjajah' itulah yang harus ditiru karena dianggap lebih unggul. Ini semua sudah terpola dan membentuk semacam blunder psikologis tertentu yang khas pada masyarakat bekas jajahan (Taum, 2011, hlm. 5).

Kehidupan sastra, termasuk sastra lisan berada dalam bingkai sosiologis seperti itu. Oleh karena pemerintah sendiri, dari pusat sampai daerah, tidak memiliki suatu strategi kebudayaan yang jelas, maka sastra dan kebudayaan lisan kini menghadapi dilema yang dicemaskan itu, masa silam yang menjauh dan masa depan yang belum pasti. Bahwa Indonesia tidak memiliki sebuah strategi kebudayaan yang memadai, karena terlalu terfokus pada ideologi pembangunan fisik-ekonomi.

Pudentia (dalam Suaka, 2014) menyebutkan, salah satu warisan budaya yang amat berharga dan penting dalam pembentukan identitas dan karakter bangsa adalah Intangiable Cultural Heritage (ICH). Unesco dalam konvensi tanggal 16 Oktober 2003 menyebutkan salah satu unsur penting dalam ICH adalah tradisi lisan. Tradisi lisan sebagai produk kultural yang kreatif tidak hanya berupa mite, legenda, dongeng, dan cerita lainnya, tetapi juga mengandung berbagai hal yang menyangkut hidup dan kehidupan komunitas pemiliknya, misalnya kearifan lokal (local wisdom), system nilai, pengetahuan tradisional (local knowledge), sistem kepercayaan dan religi, kaidah sosial, etos kerja, sistem pengobatan, mitologi, sejarah, dan berbagai hasil seni.

Sastra merupakan sebuah bidang 'existential knowledge' yang penting dipelajari sebagai upaya mencari dan menemukan kebenaran kemanusiaan, karena sastra adalah deskripsi pengalaman dan persepsi kemanusiaan yang memiliki dimensi personal dan sosial. Sastra, karena itu, dianggap sebagai jendela untuk mengintip hati manusia dan berbagi pengalaman dan kerinduan kemanusiaan. Terabaikannya sastra lisan dalam dunia pendidikan (sekolah) selama ini cukup memprihatinkan, mengingat kenyataan bahwa akar budaya bangsa tersimpan dalam berbagai karya sastra nusantara, baik tulisan maupun lisan (Taum, 2011, hlm. 6)

Menurut Pudentia (dalam Taum, 2011) kematian sebuah tradisi lisan bisa berarti kita kehilangan sebuah ensiklopedia sebuah masyarakat. Sastra lisan itu diamankan turun temurun lewat berbagai tuturan lisan seperti dongeng, mitologi, fabel, peribahasa, tamsil, bidal, dan sebagainya.

Beranjak dari kekhawatiran terhadap kematian tradisi lisan ini, maka penelitian ini mencoba mengangkat tradisi lisan terutama cerita rakyat (cerita rakyat Indragiri) sebagai bahan pembelajaran sastra di sekolah dasar. Materi cerita rakyat dianggap perlu diberikan di sekolahsekolah, terutama sekolah dasar, sebagai upaya pengenalan budaya dan tradisi daerah yang bisa membantu pembentukan karakter anak didik. Oleh sebab itu, perlu dipilih cerita rakyat yang tepat untuk anak usia sekolah dasar, yakni usia 7 - 12 tahun.

Melalui cerita rakyat, diharapkan anak didik bisa mengambil hikmah dan pesan-pesan positif, yang bisa mereka amalkan dalam kehidupan mereka seharihari. Untuk itu, diharapkan sekolah dan guru memberikan ruang dan waktu yang cukup untuk pembelajaran sastra terutama cerita rakyat. Pada penelitian ini, cerita rakyat yang akan dijadikan sebagai bahan pengajaran adalah cerita rakyat yang berasal dari Indragiri, Riau.

Penelitian tentang cerita rakyat telah sangat banyak dilakukan. Seperti "Dongeng Jawa Sebagai Pembentuk Karakter Anak" yang ditulis oleh Dewi Pusposari. Penelitian ini menyimpulkan bahwa terdapat sepuluh nilai pendidikan karakter bangsa yang terdapat dalam dongeng Jawa, yakni nilai relegius, jujur, disiplin, kerja keras, mandiri, rasa ingin tahu, semangat kebangsaan, menjunjung tinggi tata karma, 
bersahabat, dan cinta damai (Pusposari, 2015). Penelitian lainnya berjudul "Penentuan Cerita Rakyat Sentani, Jayapura, Kasuari dan Burung Pipit Sebagai Bahan Bacaan Siswa SD" oleh Normawati. Penelitian ini menyimpulkan bahwa cerita "Kasuari dan Burung Pipit" dapat dijadikan sebagai bahan bacaan untuk anak SD (usia 7-12 tahun). Cerita "Kasuari dan Burung Pipit" mengandung nilai karakter yang berhubungan dengan diri sendiri meliputi karakter bertanggung jawab, kerja keras, dan percaya diri (Normawati, 2014).

Muntihanah (2016) juga melakukan penelitian yang berjudul "Cerita Ebhi dan Khandei sebagai Bahan Bacaan Anak. Muntihanah menyimpulkan penelitiannya bahwa cerita Ebhi dan Khandei juga mengandung nilai karakter yang berhubungan dengan diri sendiri, berupa karakter jujur dan nilai karakter dalam hubungannya dengan sesame, berupa karakter yang patuh pada aturan-aturan sosial. Namun, penulis masih merasa perlu mengangkat cerita rakyat Indragiri sebagai bahan pembentukan karakter anak (tingkat sekolah dasar). Diharapkan penelitian ini bisa dijadikan acuan bagi guru-guru sekolah dasar di Riau dalam memberikan bahan bacaan bagi siswa mereka. Guru bisa memilihkan cerita rakyat Indragiri yang dianggap tepat dan cocok bagi siswa tingkat sekolah dasar.

Karya sastra selain berfungsi sebagai hiburan, juga memiliki fungsi sebagai pendidikan. Seorang penyair besar Romawi kuno, Horatius (65-8 SM), berpandangan bahwa karya sastra berfungsi sekaligus bertujuan sebagai utile (bermanfaat) dan dulce (nikmat, menyenangkan). Jadi utile at dulce, bermanfaat dan menyenangkan. Bermanfaat karena pembaca dapat menarik pelajaran yang berharga ketika membaca karya sastra dan mungkin bisa menjadi pedoman dalam hidup karena mengungkapkan nilai-nilai luhur (Sehandi, 2016, hlm. 16).

Masih menurut Sehandi (2016) meskipun sebuah karya sastra mengisahkan hal-hal yang tidak terpuji, tetapi bagaimanapun pembaca masih bisa menarik pelajaran darinya. Pembaca dapat mengambil hikmah dari cerita tersebut bahwa hal-hal tidak baik yang terdapat di dalam cerita adalah sesuatu yang harus dihindari. Pembaca akan merasa diingatkan dan menyadari untuk tidak melakukan hal tidak terpuji tersebut.

Secara umum, para ahli sastra merincikan fungsi karya sastra sebagai (1) Sebagai ekspresi keindahan, (2) Sebagai sarana hiburan, (3) Sebagai sarana pendidikan, (4) Sebagai sarana penanaman nilai, (5) Sebagai sarana melestarikan budaya bangsa.

Sebagai penanaman nilai, karya sastra mengandung bermacam-macam nilai kehidupan, seperti nilai moral, etika, estetika, religious, sosial, budaya, hokum, dan lain-lan. Nilai-nilai kemanusian ini sangat dibutuhkan bagi hidup dan kehidupan seseorang. Nilai-nilai itu berfungsi sebagai nasihat bagi para penikmat karya sastra. Pembaca yang peka akan nilai-nilai yang ditawarkan dalam karya sastra berpengaruh besar dalam mengubah perilaku hidupnya, melaksanakan kebiakan dan meninggalkan keburukan. Begitu juga, ketika sebuah cerita menjelaskan akibat perbuatan tercela yang dilakukan oleh seseorang berdampak tidak baik, sehingga akan timbul pemikiran pembaca untuk tidak melakukan dan mengikuti hal-hal yang kurang baik tersebut (Sehandi, 2016, hlm. 19).

Tidak jauh berbeda dengan pendapat Nurgiyantoro (2013) bahwa berbagai teks kesastraan diyakini mengandung unsur moral dan nilai-nilai yang dapat dijadikan "bahan baku" pendidikan dan pembentukan karakter. Karya sastra dapat tampil dengan menawarkan alternatif model kehidupan yang diidealkan yang mencakup berbagai aspek kehidupan seperti cara berpikir, bersikap, berasa, bertindak, cara memandang dan memperlakukan sesuatu. Sastra dipersepsi sebagai suatu fakta sosial yang menyimpan pesan yang mempu 
menggerakkan emosi pembaca untuk bersikap dan berbuat sesuatu.

Sastra mempunyai peran sebagai salah satu alat pendidikan yang seharusnya dimanfaatkan dalam dunia pendidikan, khususnya dalam upaya pembentukan dan pengembangan kepribadian anak, peran sebagai character buiding (Nurgiyantoro, 2013, hlm. 434). Jika dimanfaatkan secara benar dan dilakukan dengan strategi yang tepat, sastra diyakini mampu berperan dalam pengembangan manusia yang seutuhnya dengan cara yang menyenangkan. Hal ini karena pembelajaran melalui sastra adalah pembelajaran secara tidak langsung. Anak tidak akan menyadari bahwa mereka sebenarnya sedang mendapatkan penanaman nilai-nilai karakter untuk kepribadian mereka yang lebih baik. Maka sastra bisa dikatakan mampu menunjang pembentukan karakter anak yang masih dalam tahap perkembangan lewat teladan kehidupan tersebut.

Begitu juga dengan cerita rakyat, sebagai sebuah karya sastra tradisonal, cerita rakyat mengandung nilai-nilai kehidupan yang memuat pesan moral yang yang dapat dijadikan pembelajaran bagi pembaca, terutama bagi anak-anak. Pesan moral yang terkandung di dalam sebuah cerita rakyat adalah nilai-nilai pendidikan karakter. Kata karakter berarti tabiat, sifatsifat kejiwaan, akhlak atau budi pekerti yang membedakan seseorang dengan yang lain, atau watak (Kamus Besar Bahasa Indonesia). Orang yang berkarakter berarti yang berkepribadian, berperilaku, bersifat orang, bertabiat, atau berwatak. Kepribadian merupakan ciri, karakteristik, atau sifat khas dari diri seseorang yang bersumber dari bentukan-bentukan yang diterima dari lingkungan (Sugihastuti, 2016, hlm.15).

Secara universal menurut Gufron (2010) karakter dirumuskan sebagai nilai hidup bersama berdasarkan pilar: kedamaian, menghargai, kerjasama, kebebasan, kebahagiaan, kejujuran, kerendahhatian, kasih sayang, tanggung jawab, kesederhanaan, toleransi, dan persatuan. Sejalan dengan itu, Peraturan Pemerintah Nomor 23 tahun 2006 (dalam Muntihanah, 2016) menetapkan 20 nilai karakter yang akan diwujudkan pada periode 2010-2025. Nilai-nilai karakter tersebut adalah a) nilai karakter dalam hubungannya dengan Tuhan YME yang berupa nilai relegius; b) Nilai karakter dalam hubungannya dengan diri sendiri meliputi (1) jujur, (2), bertanggung jawab, (3) bergaya hidup sehat, (4) disiplin, (5) kerja keras, (6) percaya diri, (7) berjiwa usaha, (8) berpikir logis, kreatif, inovatif, (9) mandiri, (10) ingin tahu, dan (11) cinta ilmu; c) Nilai karakter dalam hubungannya dengan sesama manusia meliputi (1) sadar akan hak dan kewajiban diri dan orang lain, (2) patuh pada aturan-aturan sosial, (3) menghargai karya dan prstasi orang lain, (4) santun, dan (5) demokratis; d) Nilai karakter dalam hubungannya dengan lingkungan meliputi peduli sosial dan lingkungan; e) Nilai kebangsaan meliputi (1) nasionalisme dan (2) menghargai keberagaman.

Untuk menemukan nilai-nilai karakter dan pesan moral yang terdapat di dalam sebuah karya sastra, dalam hal ini cerita rakyat, maka analisis struktural perlu dilakukan. Masih menurut Nurgiyantoro (2013) kajian struktural teks-teks kesastraan penting untuk memahami makna keseluruhan karya yang bersangkutan. Jika membaca cerita fiksi, kita akan bertemu dengan sejumlah tokoh, berbagai peristiwa yang dilakukan atau dikenakan kepada para tokoh, tempat, waktu, dan latar sosial budaya di mana cerita itu terjadi, dan lainlain. Kesemuanya berjalan serempak dan saling mendukung. Misalnya bagaimana tokoh saling berhubungan, berbagai peristiwa saling terkait walaupun penceritaannya berjauhan, bagaimana latar sosial budaya memfasilitasi dan membentuk karakter tokoh, dan lain-lain. Hal ini semuanya dapat berjalan dengan baik, cerita dapat dipahami dengan baik 
karena ada benang merah yang mengatur dan menghubungkan semua elemen, yaitu struktur.

Alur berkaitan dengan masalah urutan penyajian cerita, tetapi bukan hanya masalah saja yang menjadi persoalan alur. Menurut Lukens (dalam Nurgiyantoro, 2013) alur merupakan urutan kejadian yang memperlihatkan tingkah laku tokoh dalam aksinya. Pembicaraan alur akan melibatkan masalah peristiwa dan aksi yang dilakukan dan ditimpakan kepada tokoh cerita.

Sementara Stanton (dalam

Nurgiyantoro, 2013) mengemukakan bahwa plot (alur) adalah cerita yang berisi urutan kejadian, namun tiap kejadian itu hanya dihubungkan secara sebab akibat, peristiwa yang satu disebabkan atau menyebabkan terjadinya peristiwa yang lain. Abrams (dalam Nurgiyantoro, 2013) mengatakan bahwa plot sebuah fiksi merupakan struktur peristiwa-peristiwa, yaitu sebagaimana yang terlihat dalam pengurutan dan penyajian berbagai peristiwa tersebut untuk mencapai efek artistic dan emosional tertentu.

Untuk memperoleh keutuhan sebuah plot cerita, Aristoteles menurut Abrams (dalam Nurgiyantoro, 2013) mengemukakan bahwa sebuah plot haruslah terdiri dari tahap awal, tahap tengah, dan tahap akhir. Tahap awal sebuah cerita biasanya disebut tahap perkenalan. Tahap perkenalan pada umumnya berisi sejumlah informasi penting yang berkaitan dengan berkaitan dengan berbagai hal yang akan dikisahkan pada tahap-tahap berikutnya.

Tahap tengah cerita dapat disebut sebagai tahap pertikaian yang menampilkan pertentangan atau konflik yang sudah mulai dimunculkan pada tahap sebelumnya, menjadi semakin meningkat, semakin menegangkan. Dan tahap akhir, dapat juga disebut tahap pelarian, menampilkan adegan tertentu sebagai akibat klimaks. Bagian ini misalnya (antara lain) berisi bagaimana kesudahan cerita, atau menyarankan pada hal bagaimanakah akhir sebuah cerita.
Tokoh cerita (character), sebagaimana dikemukakan Abrams (dalam Nurgiyantoro, 2013) adalah orang yang ditampilkan dalam sesuatu karya naratif, atau drama, yang oleh pembaca ditafsirkan memiliki kualitas moral dan kecendrungan tertentu seperti yang diekspresikan dalam ucapan dan apa yang dilakukan dalam tindakan. Tidak berbeda dengan Abrams, Baldic (dalam Nurgiyantoro, 2013) menjelaskan bahwa tokoh adalah orang yang menjadi pelaku dalam cerita fiksi atau drama. Dalam bacaan cerita anak tokoh dapat berupa manusia, binatang, atau makhluk dan objek lain seperti makhluk halus (peri, hantu) dan tetumbuhan.

Tema adalah makna yang mengikat keseluruhan unsur cerita sehingga cerita itu hadir sebagai sebuah kesatuan yang padu. Berbagai unsur fiksi seperti alur, tokoh, alat, sudut pandang, stile dan lain-lain berkaitan secara sinergis untuk bersamasama mendukung eksistensi tema (Nurgiyantoro, 2013, hlm. 80). Karena berfungsi mengikat keseluruhan aspek cerita secara padu dan sinergis, oleh Lukens (dalam Nurgiyantoro, 2013) tema mengikat berbagai unsur intrinsik yang membangun cerita sehingga tampil sebagai sebuah kesatupaduan yang harmonis. Dalam kaitan ini, tema merupakan dasar pengembangan sebuah cerita. Pemahaman terhadapa tema suatu cerita fiksi adalah pemahaman terhadap makna cerita itu sendiri. Tema sebuah cerita fiksi merupakan gagasan utama atau makna utama cerita.

Sementara aspek tema dan moral dalam sebuah cerita adakalanya bersifat tumpang tindih, dalam arti pernyataan tema juga sekaligus merupakan moral, atau sebaliknya (Nurgiyantoro, 2013, hlm. 81). Hal itu merupakan hal yang wajar karena keduanya merupakan makna sebuah cerita. Moral merupakan salah satu wujud tema dalam bentuk yang sederhana, walau tidak semua tema mesti sekaligus merupakan nilai moral. Tema mengusung kebenaran, moral memberikan ajaran. 


\section{METODE PENELITIAN}

Penelitian ini menggunakan metode deskriptif analisis, yaitu mendiskripsikan fakta-fakta kemudian dilanjutkan dengan anlisis. Secara etimologis, deskripsi analisis berarti menguraikan, tetapi tidak sematamata menguraikan saja, di dalamnya juga memberikan pemahaman dan penjelasan secukupnya (Ratna, 2012, hlm. 53). Data penelitian diperoleh dari sastra lisan Indragiri, Riau. Teknik analisis data yang digunakan, yaitu membaca beberapa cerita rakyat Indragiri yang berjudul "Asal Mula Nyamuk Takut Kepada Asap", dan "Si Bungsu", memaknai cerita tersebut, menentukan tema, pesan, dan karakter masing-masing tokoh cerita rakyat tersebut dan menyimpulkannya.

Sementara pendekatan yang digunakan adalah pendekatan moral. Pendekatan moral bertolak dari asumsi dasar bahwa salah satu tujuan kehadiran sastra di tengah-tengah masyarakat pembaca adalah sebagai upaya untuk meningkatkan harkat dan martabat manusia sebagai makhluk berbudaya, berpikir, dan berketuhanan (Semi, 2012, hlm. 89).

\section{PEMBAHASAN}

Cerita rakyat Indragiri cukup banyak dan beragam. Akan tetapi, pada penelitian ini hanya akan dibahas beberapa cerita rakyat yang memiliki tema sesuai untuk anak usia $7-12$ tahun. Kesesuaian tersebut dilihat dari tema yang tidak mengandung unsurunsur porno aksi, tidak mengangkat tentang perkawinan dan pernikahan, tidak mengandung unsur kekerasan, dan tidak berbau sara.

\section{Ringkasan Cerita Asal Mula Nyamuk Takut Kepada Asap}

Cerita rakyat ini bercerita seekor nyamuk. Konon, pada zaman dahulu, nyamuk itu bertubuh besar, sebesar seekor ayam jantan. Jika nyamuk itu menghisap darah seseorang, maka orang tersebut akan mati karena kehabisan darah. Setiap hari nyamuk menghisap darah satu orang manusia. Kabar tentang nyamuk ini sampai juga pada sebuah kerajaan yang negerinya aman dan makmur. Raja merasa takut jika nyamuk akan menghisap darahnya. Akhirnya raja pun berunding dengan sang nyamuk. Nyamuk tidak akan menghisap darah sembarang orang asalkan raja menyediakan seorang manusia setiap harinya.

Sejak kesepakatan itu, setiap hari raja menyediakan satu orang rakyatnya untuk dihisap darahnya oleh sang nyamuk. Lama kelamaan penduduk semakin berkurang karena setiap hari selalu ada yang mati oleh nyamuk. Suatu hari tibalah giliran seorang anak miskin. Ayahnya telah lama meninggal dunia. Ia hidup berdua dengan ibunya yang sudah tua.

Pada hari yang ditetapkan pergilah si anak miskin tersebut ke tempat kediaman sang nyamuk. Sebelum pergi, ibunya membekalinya dengan setongkol jagung. Sambil menunggu nyamuk datang untuk menghisap darahnya, si anak ingin membakar dulu jagung pemberian ibunya untuk kemudian dimakannya. Ia mengumpulkan kayu bakar dan membakarnya lalu meletakkan jagung pemberian ibunya di atas bara yang mulai memerah.

Setelah jagung itu masak, mulailah ia memakannya. Sambil memakan jagung bakar itu, air matanya meleleh. Teringat ia akan ibunya yang telah tua dan sakitsakitan. Setelah ia mati nanti, tentu ibunya akan tinggal sendirian. Kemudian ia pun berdoa, "Tuhan tolonglah ibu hamba, peliharalah dia, karena hamba tidak dapat lagi memeliharanya." Doa itu diulangnya berkali-kali sambil menangis.

Ia tidak takut mati. Hal yang disedihkan dan ditangiskannya adalah ibunya yang akan tinggal sendirian tanpa dirinya. Tiba-tiba asap dari api di depannya membesar dan menyerupai manusia. Asap itu bertanya, mengapa ia menangis. Si anak pun menceritakan bahwa ia menangis karena memikirkan nasib ibunya. "Jadi 
engkau menangis bukan karena takut mati? Tetapi karena memikirkan ibumu dan karena begitu menyanyangi ibumu?" tanya sang asap. "Benar, bagi hamba sendiri, mati adalah hak Allah. Aku hanya memikirkan ibuku," jawab si anak masih dengan air mata mengalir.

Lalu asap pun mengatakan akan membantu anak tersebut, karena kecintaan sang anak yang begitu besar pada ibunya. Asap menuruh si anak untuk membuat api semakin besar. Jika nanti nyamuk itu datang, api telah besar, maka asaplah yang akan menghalau sang nyamuk. Beberapa saat kemudian, nyamuk pun keluar dari sarangnya. Nyamuk mendekati si anak miskin, tetapi nyamuk tidak bisa makin dekat karena asap menghalanginya. Asap makin tinggi menggumpal ke angkasa, nyamuk pun terbang menjauh entah ke mana.

Si anak miskin mengucapkan syukur kepada Allah karena telah mengutus asap untuk menolongnya. Tidak lupa ia mengucapkan terima kasih pada asap. Lalu ia pun pamit pulang pada asap, ia ingin segera menjumpai ibunya. Asap mendoakan si anak tersebut agar selalu menjadi anak yang berbakti kepada ibunya. Selagi di dunia ini masih ada anak yang taat dan berbakti kepada ayah dan ibunya, asap berjanji akan selalu menolong manusia untuk mengusir nyamuk.

Akhirnya seluruh negeri mengetahui kelemahan nyamuk yang takut kepada asap. Sementara tubuh nyamuk akhirnya makin lama makin mengecil karena tidak lagi mengisap darah manusia. Sampai saat inipun nyamuk masih takut pada asap.

\section{Alur}

Tahap awal dari cerita 'Asal Mula Nyamuk Takut kepada Asap' adalah ukuran badan nyamuk yang pada mulanya berukuran besar, sebesar ayam jantan. Setiap hari nyamuk menghisap darah seorang manusia. Orang yang dihisap darahnya tersebut akan mati kehabisan darah. Cerita tentang nyamuk ini sampai ke telinga raja yang memiliki kerajaan yang rakyatnya aman dan tentram. Raja yang merasa takut jika darahnya dihisap oleh nyamuk, mengajak nyamuk berunding.

Perundingan raja dengan nyamuk menghasilkan sebuah kesepakatan. Inilah yang menjadi awal konflik dari cerita "Asal Mula Nyamuk Takut kepada Asap" ini. Raja harus menyediakan satu orang rakyatnya setiap hari untuk dihisap darahnya oleh nyamuk. Lama kelamaan, penduduk pun makin berkurang, karena setiap hari ada yang mati setelah darahnya dihisap oleh sang nyamuk.

Tahap Tengah, cerita masuk pada konflik berikutnya, yakni ketika tiba giliran seorang anak laki-laki, anak dari seorang janda miskin. Anak laki-laki yang begitu berbakti dan menyanyangi ibunya itu berangkat menuju tempat kediaman nyamuk berbekal setongkol jagung pemberian ibunya. Ia begitu sedih meninggalkan ibunya yang hanya hidup sendirian setelah kepergiannya. Asap pun berjanji akan menolong si anak. Asap tersebut menyuruh sang anak untuk membuat api lebih besar, dan jika nyamuk ke luar dari sarangnya.

Sesampainya di kediaman sang nyamuk, ternyata nyamuk masih tidur. Anak laki-laki itupun mengumpulkan beberapa kayu bakar dan segera membuat api unggun untuk membakar jagungnya. Setelah jagungnya masak, ia pun mulai memakan jagung bakar tersebut. Sambil makan jagung bakar, air matanya meleleh membasahi pipinya. Ia tidak takut mati, tetapi ia sangat sedih memikirkan nasib ibunya jika ia sudah tidak ada. Siapa yang akan menjaga ibunya kelak.

Cerita mulai naik memasuki klimaksnya ketika asap di depannya mulai memebesar dan menyerupai manusia. Jelmaan seperti manusia itu pun bertanya pada si anak, mengapa ia menangis. Anak laki-laki itu menceritakan semua kesedihannya karena harus meninggalkan ibunya sendirian. Asap pun berjanji akan menolong si anak. Asap menyuruh sang 
anak untuk membuat api lebih besar, dan jika nyamuk ke luar dari sarangnya, asaplah yang akan mengusir nyamuk tersebut.

Anak laki-laki itu pun mengikuti apa yang diperintahkan oleh asap. Ketika nyamuk ke luar dari sarangnya, nyamuk tersebut mencoba mendekati anak laki-laki itu. Akan tetapi nyamuk tidak bisa mendekat karena dihalangi oleh asap. Cerita pun sampai pada klimaksnya, asap makin tinggi membumbung ke angkasa. Nyamuk merasa takut lalu terbang jauh melarikan diri.

Tahap akhir, cerita menuju anti klimaksnya, kisah tentang nyamuk yang takut pada asap tersebar ke seluruh pelosok kerajaan. Rakyat akhirnya mengetahui kelemahan sang nyamuk. Sementara tubuh nyamuk makin lama makin mengecil karena tidak lagi menghisap darah manusia.

\section{Penokohan}

Tokoh dalam cerita Asal Mula Nyamuk Takut kepada Asap hanya tiga tokoh, yakni nyamuk, anak laki-laki, asap dan raja. Tokoh baik dalam cerita ini adalah anak laki-laki dan asap. Anak laki-laki tersebut memiliki karakter relegius, bertanggung jawab, mandiri, santun, dan kasih sayang.

Nilai relegius si anak terlihat ketika ia sedang menunggu kedatangan sang nyamuk. Anak tersebut berdoa kepada Tuhan, agar Tuhan menjaga ibunya setelah ia sudah tidak ada.

Setelah ia mati nanti, tentu ibunya akan tinggal sendirian. Kemudian ia pun berdoa, "Tuhan tolonglah ibu hamba, peliharalah dia, karena hamba tidak dapat lagi memeliharanya." Doa itu diulangnya berkali-kali sambil menangis (Hermansyah, 2014, hlm. 19).

Karakter si anak menunjukkan kalau ia memiliki keimanan yang kuat. Iman yang telah membuat si anak iklas menerima kematiannya. Ia mengatakan bahwa ia tidak takut mati, karena baginya kematiannya adalah hak Allah atas dirinya. Ia bisa menerimanya dengan iklas.
Hal ini bisa dijadikan sebagai contoh dan teladan yang baik dalam upaya pembentukan karakter anak didik. Bahwa sebagai manusia kita harus memiliki keyakinan akan takdir Allah, bahwa takdir Allah adalah suatu ketetapan yang harus diterima oleh seorang anak manusia. Sebagai seorang hamba Allah, kita harus bisa menerima takdir tersebut dengan sabar dan iklas. Si anak miskin dalam cerita di atas telah memiliki keyakinan akan takdir dari Allah. Semua itu tidak lain karena iman di dalam dadanya.

Hal lain yang dapat diambil hikmahnya adalah selalulah memohon dan meminta hanya kepada Allah. Dalam situasi dan kondisi yang seperti apa pun, selalu lah meminta kepada Allah melalui doa. Si anak miskin telah melakukan hal tersebut. Sebelum nyamuk menghisap darahnya, ia berdoa kepada Tuhan agar Tuhan menjaga ibunya jika ia sudah tidak ada kelak. Anak tersebut berdoa dengan sepenuh hati dalam tangisan dan air mata. Kesungguhannya dalam berdoa telah mendapatkan jawaban dari Tuhan. Tuhan segera mengirimkan pertolongannya melalui asap.

Karakter bertanggung jawab si anak terlihat dari doanya kepada Tuhan, agar Tuhan menjaga ibunya. Setelah ia mati, tidak ada lagi orang yang akan memelihara ibunya. Dari hal ini terlihat jika si anak sangat ingin menjaga dan merawat ibunya. Setelah ayahnya meninggal, ia dan ibunya hanya tinggal berdua saja. Tidak ada orang lain yang akan mengurus ibunya.

Karakter berikutnya dari si anak adalah percaya diri. Ini dibuktikannya dengan sikap berani dan tak gentar si anak menghadapi ancaman. Sebagai seorang anak manusia yang akan dipersembahkan kepada seekor nyamuk besar untuk diisap darahnya, anak miskin tersebut telah menunjukkan sikap yang tegar. Tidak terlihat rasa takut dan gentarnya menghadapi nyamuk. Meskipun ia tahu, setelah nyamuk menghisap darahnya ia akan segera mati seperti penduduk kerajaan yang lainnya. 
Karakter santun dan memiliki kasih sayang. Hal ini terlihat dari sikap si anak kepada ibunya, yang hanya memikirkan nasib ibunya. Ia adalah anak yang berbakti kepada orang tuanya. Cerita ini bisa menjadi contoh dan menjadi teladan bagi anak didik di sekolah. Bahwa seorang anak harus menyayangi orang tuanya dengan tulus dan iklas. Seorang anak harus mau menjaga dan merawat ibunya jika ibunya telah menjadi tua kelak.

\section{Tema}

Cerita di atas memperlihatkan kasih sayang seorang anak kepada ibunya. Kasih sayang dan kecintaannya yang begitu besar pada sang ibu telah menyelamatkan si anak dari seekor nyamuk yang mematikan. Bagi si anak miskin tersebut, hidupnya hanya untuk berbakti dan mengabdi kepada ibunya. Rasa sedih dan tangisannya sebelum darahnya diisap oleh sang nyamuk bukan karena ia takut mati, tapi semata karena ia memikirkan nasib ibunya. Ia sedih memikirkan bagaimana nasib ibunya kelak jika ia sudah tidak ada. Siapa yang akan mengurus dan merawat ibunya yang sudah tua.

Doa si anak agar Tuhan menjaga ibunya jika kelak ia sudah tidak ada dikabulkan Tuhan saat itu juga. Lewat asap, Tuhan mengirimkan pertolongannya. Asap berhasil menghalau nyamuk pergi jauh dan tidak jadi menghisap darah si anak. Anak miskin itu pun akhirnya selamat dan bisa kembali kepada ibunya. Betapa senang dan bahagianya si anak bisa kembali menjaga dan merawat ibunya.

\section{Pesan Moral}

Pesan yang dapat diambil dari cerita Asal Mula Nyamuk Takut kepada Asap, selalulah memohon dan meminta hanya kepada Allah. Dalam situasi dan kondisi yang seperti apa pun, selalu lah meminta kepada Allah melalui doa. Si anak miskin telah melakukan hal tersebut. Sebelum nyamuk menghisap darahnya, ia berdoa kepada Tuhan agar Tuhan menjaga ibunya jika ia sudah tidak ada kelak. Anak tersebut berdoa dengan sepenuh hati dalam tangisan dan air mata. Kesungguhannya dalam berdoa telah mendapatkan jawaban dari Tuhan. Tuhan segera mengirimkan pertolongannya melalui asap.

Pesan kedua, jadilah anak yang berbakti pada orang tua. Tugas seorang anak adalah menyayangi dan menghormati kedua orang tuanya. Anak berkewajiban mengurus dan merawat kedua orang tuanya ketika orang tuanya telah memasuki usia tua. Anak harus bersikap santun dan bersikap baik pada kedua orang tuanya.

Cerita rakyat yang berjudul "Asal Mula Nyamuk Takut Kepada Asap," memang sarat dengan pesan-pesan moral yang dapat dijadikan sebagai bahan untuk pembentukan karakter anak didik. Sikap si anak miskin dapat dijadikan contoh dan teladan yang baik bagi anak didik. Oleh sebab itu cerita rakyat ini sangat tepat dijadikan sebagai bahan pengajaran sastra di sekolah dasar untuk mata pelajaran bahasa Indonesia.

\section{Latar}

Cerita Asal Mula Nyamuk Takut Kepada Asap tidak menggambarkan latar secara jelas. Di dalam cerita hanya disebutkan jika cerita terjadi pada 'sebuah negeri'. Negeri tersebut merupakan sebuah kerajaan yang aman dan makmur. Kerajaan yang dipimpin oleh seorang raja. Akan tetapi nama negeri dan kerajaannya tidak disebutkan.

Sementara untuk latar waktu, cerita ini terjadi pada zaman dahulu ketika di Indonesia masih berdiri kerajaan-kerajaan. Akan tetapi, seperti halnya latar tempat, latar waktu pada cerita Asal Mula Nyamuk Takut Kepada Asap juga tidak jelas. Tidak diceritakan tahun pastinya cerita ini terjadi.

\section{Ringkasan Cerita Si Bungsu}

Pada zaman dahulu hiduplah sepasang suami istri dengan tujuh orang anak gadisnya. Di antara ketujuh anak gadisnya, anak yang paling bungsulah yang paling cantik dan paling baik hatinya. Hal ini 
membuat kedua orang tua mereka seperti lebih menyayangi dan lebih memanjakan si Bungsu. Keenam kakak si Bungsu merasa cemburu atas perlakuan orang tua mereka pada si Bungsu.

Keenam kakak si Bungsu selalu disuruh mencari kayu bakar ke hutan oleh kedua orang tua mereka. Si Bungsu tidak pernah diizinkan untuk ikut dengan mereka. Suatu hari kakak tertua memohon izin kepada ibu mereka agar mengizinkan si Bungsu untuk ikut dengan mereka mencari kayu ke hutan. Awalnya sang ibu keberatan melepas si bungsu. Akan tetapi kakakkakak Bungsu lainnya ikut memohon dan membujuk sang ibu. Akhirnya ayah dan ibu mereka pun memberikan izin.

Sesampainya di hutan, si Bungsu disuruh oleh keenam kakaknya untuk menebang kayu sendirian. Sementara mereka hanya duduk-duduk saja melihat si Bungsu. Seharian si Bungsu menebang kayu dan memotong-motong kayu dan mengikatnya untuk dibawa pulang. Si Bungsu disisakan sedikit saja nasi tanpa lauk oleh kakak-kakaknya. Semua makanan dan minuman yang telah dibungkuskan oleh ibu mereka, mereka habiskan tanpa mengingat si Bungsu. Dalam hati si Bungsu berdoa, "Ya Allah, tunjukkanlah kakakkakak hamba kalau mereka salah, dan hukumlah hamba jika hamba yang salah."

Ketika hari telah sore, mereka bertujuh pun segera pulang ke rumah. Bungsu membawa ikatan kayu yang paling besar. Di perjalanan barulah Bungsu merasakan tangannya luka-luka karena tergores kayu dan ranting kayu. Terasa perih. Akan tetapi Bungsu diam saja. Sampai di rumah, Bungsu juga tidak menceritkan perlakuan keenam orang kakaknya kepada kedua orang tuanya. Ketika ditanyakan bagaimana perjalanan Bungsu dan keenam kakaknya, Bungsu cerpat menjawab bahwa perjalanan mereka sangat menyenangkan. Jika nanti kakakkakaknya pergi ke hutan lagi, Bungsu mengatakan ingin ikut lagi dengan kakakkakkanya. Tentu saja keenam kakak
Bungsu kaget dan heran karena Bungsu tidak mengadu kepada ayah dan ibu mereka.

Esok paginya mereka bertujuh pergi mandi dan mencuci ke sungai. Ketika mereka telah sama-sama berada di dalam air sungai, keenam kakak Bungsu bisa melihat goresan-goresan luka berwarna merah di tangan Bungsu. Bungsu sudah merasa lukanya akan terasa amat perih jika terkena air. Akan tetapi anehnya begitu Bungsu menyiramkan air ke tangannya, Bungsu tidak merasakan perih sedikitpun. Malah sebaliknya luka-luka itu seketika hilang tanpa bekas. Bungsu dan keenam kakaknya merasa heran dan takjud.

$\mathrm{Si}$ Bungsu meminta maaf kepada kakak-kakaknya, karena menurut Bungsu karena dirinya, kakak-kakkanya mungkin telah merasa cemburu padanya. Bungsu mengatakan jika ia iklas menerima semua perlakuan kakak-kakaknya. Disebabkan karena keiklasan si Bungsu itu jugalah mungkin luka-luka di tangan si Bungsu bisa sehat setelah terkena air.

Keenam kakak si Bungsu merasa malu atas sikap mereka pada Bungsu. Mereka telah bersikap dan berbuat jahat kepada si Bungsu. Sementara si Bungsu tetap baik kepada mereka. Mereka berenam pun meminta maaf kepada si Bungsu. Dengan penuh penyesalan mereka memeluk si Bungsu. Si Bungsu sangat bahagia, dan ia mengangkat kedua tangannya, "Ya Allah, terima kasih engkau telah mengabulkan doa hamba."

\section{Alur}

Tahap awal, kehidupan sepasang suami istri dengan tujuh orang anak gadisnya. Di antara ketujuh orang anak gadis mereka, si bungsulah yang paling cantik dan paling baik hatinya. Ia selalu ramah kepada siapa saja. Si Bungsu juga yang paling dimanjakan oleh kedua orang tuanya. Hal ini membuat kakak-kakak si Bungsu merasa iri hati kepada si Bungsu.

Keenam kakak si Bungsu selalu disuruh mencari kayu bakar ke hutan oleh 
kedua orang tua mereka. Sementara si Bungsu tidak pernah diizinkan untuk ikut. Keenam kakak si Bungsu selalu memohon kepada orang tua mereka agar si Bungsu diizinkan ikut dengan mereka. Akan tetapi orang tua mereka tidak pernah mengizinkan. Namun pada suatu hari, akhirnya orang tua mereka mengizinkan Bungsu ikut dengan kakak-kakaknya.

Tahap tengah, Pada tahap ini konflik sudah mulai muncul. Konflik mulai terjadi ketika ketujuh orang gadis tersebut sampai di hutan. Keenam orang kakaknya memerintahkan Bungsu untuk menebang kayu-kayu yang yang mereka temui di hutan. Sementara kakak-kakaknya duduk di bawah sebatang pohon sambil membuka bekal makanan mereka. Mereka berenam pun makan dengan lahap tanpa memikirkan si Bungsu. Mereka hanya menyisakan sedikit makanan untuk si Bungsu, tanpa ada lauk dan sayurnya.

Akibat menebang kayu sendirian dan belum pernah melakukan sebelumnya, tangan si Bungsu jadi luka-luka. Luka-luka itu terasa amat perih. Ketika pulang ke rumah, si Bungsu juga harus membawa ikatan kayu yang paling besar disbanding kepunyaan kakak-kakaknya. Meski diperlakukan dengan tidak baik, si Bungsu tidak mengadukan perbuatan keenam orang kakaknya kepada orang tuanya.

Klimaks dari cerita si Bungsu adalah ketika mereka mandi-mandi di sungai. Kakak-kakak si Bungsu melihat jika tangan si Bungsu penuh luka dan darah. Akan tetapi, begitu si Bungsu menyiramkan air ke badan dan tangannya, seketika itu juga luka-luka di tangan Bungsu hilang tanpa bekas. Tidak ada rasa sakit sama sekali. Kakak-kakak si Bungsu pun heran melihatnya.

Tahap akhir, cerita masuk pada tahap anti klimaks (penyelesaian cerita), si Bungsu mengatakan bahwa ia minta maaf kepada kakak-kakaknya karena selama ini telah membuat kakak-kakaknya merasa cemburu kepadanya. Bungsu mengatakan bahwa ia iklas menerima perlakuan kakak- kakaknya, sebab itulah mungkin Allah menyembuhkan luka-luka di tangannya.

Akhirnya keenam kakak si Bungsu menyadari kesalahannya. Mereka menyesal telah berbuat jahat pada Bungsu. Mereka berenam pun meminta maaf pada Bungsu. Dengan penuh penyesalan mereka memeluk si Bungsu. Bungsu merasa bahagia karena Allah telah mendengar doa-doanya.

\section{Penokohan}

Karakter baik yang terdapat di dalam cerita rakyat "Si Bungsu" ini adalah religius, bertanggung jawab, kerja keras, santun, kasih sayang, dan menghargai. Karakter santun dan menghargai si Bungsu terlihat ketika si Bungsu menerima semua perlakuan tidak baik kakak-kakaknya. Bungsu tidak mencoba melawan atau membantah perintah keenam orang kakaknya. Bungsu melaksanakan semua perintah kakak-kakaknya dengan senang hati.

Karakter baik kedua yang dapat dijadikan teladan bagi anak-anak adalah karakter tanggung jawab dan kerja keras si Bungsu. Bungsu melaksanakan perintah kakak-kakaknya dengan penuh tanggung jawab. Ia bisa menebang pohon-pohon kayu yang diperintahkan oleh kakak-kakaknya. Hal ini membuktikan jika Bungsu juga seorang pekerja keras. Bungsu tidak menyerah, meski tangannya mengalami luka-luka dan berdarah. Bungsu juga mengikat kayu-kayu tersebut menjadi tujuh ikatan. Ketika pulang, Bungsu mendapatkan ikatan kayu yang paling besar dan berat dibandingkan keenam orang kakaknya. Akan tetapi Bungsu melakukan semua itu dengan penuh tanggung jawab.

Meski diperlakukan dengan semenamena, menebang pohon kayu sendirian, mendapatkan sedikit sisa makanan, dan membawa beban kayu yang lebih besar, si Bungsu tidak merasa sakit hati. Ketika sampai di rumah dan ibunya bertanya tentang perjalanannya hari ini, Bungsu malah menjawab bahwa perjalanannya menyenangkan. Bungsu mengatakan jika 
keenam kakaknya telah bersikap baik padanya. Semua ini menunjukkan bahwa Bungsu adalah seorang anak yang memiliki toleransi yang besar. Ia menyadari keenam orang kakaknya cemburu dan iri pada Bungsu karena orang tua mereka lebih memanjakan si Bungsu. Bungsu bisa menerima semua itu karena rasa toleransinya yang besar kepada kakakkakaknya.

Bungsu juga seorang anak yang memiliki kasih sayang kepada kedua orang tua dan keenam orang kakaknya. Kasih sayang itulah yang membuat Bungsu akhirnya bisa memaafkan sikap dan perlakuan keenam orang kakak-kakaknya. Bungsu tidak merasa dendam apalagi membenci kakak-kakaknya. Keenam orang kakak si Bungsu juga menunjukkan kejujuran dan kerendahhatian mereka. Mereka akhirnya menyadari kesalahan mereka pada Bungsu, lalu mereka pun meminta maaf atas kesalahan yang telah mereka perbuat tersebut.

Bungsu juga seorang anak yang relegius. Bungsu mengadukan perlakuan keenam orang kakaknya hanya kepada Tuhan. Bungsu mendoakan

\section{Tema}

$\mathrm{Si}$ Bungsu menecritakan kecemburuan enam orang kakak kandung kepada adik bungsunya. Kecemburuan kakak-kakak si Bungsu ini karena mereka menganggap kedua orang tua mereka lebih menyayangi dan memanjakan si Bungsu. Mereka pun menghukum si Bungsu dengan menyusuh si Bungsu menebang pohon-pohon ketika mereka mencari kayu bakar ke hutan. Mereka pun memberi beban kayu bakar yang lebih besar kepada Bungsu. Akan tetapi Bungsu menerima perlakuan buruk keenam kakaknya dengan sabar dan iklas. Bungsu tidak merasa marah atau sakit hati, sehingga kakak-kakak Bungsu akhirnya menyadari kesalahan mereka. Mereka pun meminta maaf kepada Bungsu.

\section{Pesan Moral}

Pesan moral yang dapat ditemukan dalam cerita "Si Bungsu" adalah a) Janganlah merasa iri dan cemburu dengan kelebihan orang lain, apalagi orang tersebut adalah saudara sendiri, seperti sikap kakak-kakak si Bungsu. b) Berani mengakui kesalahan dan berani meminta maaf. Jika menyadari telah berbuat kesalahan, maka segeralah untuk meminta maaf, seperti yang dilakukan oleh keenam orang kakak Bungsu c) Berilah maaf kepada orang yang meminta maaf kepada kita, meskipun ia telah menyakiti dan berbuat jahat kepada kita, seperti sikap si Bungsu.

\section{Latar}

Latar cerita "Si Bungsu" tidak digambarkan secara jelas. Latar tempat hanya menggambarkan pinggiran hutan tempat mereka mencari kayu bakar. Selain hutan, juga diceritakan sungai tempat mereka mandi dan mencuci. Penggambaran latar tempat yang diperoleh hanya menggambarkan dua hal tersebut. Sementara latar waktu juga tidak jelas diungkapkan. Kapan cerita ini persisnya terjadi. Di awal cerita hanya disebutkan pada zaman dahulu.

\section{PENUTUP}

Cerita rakyat seperti halnya karya sastra lainnya memiliki manfaat yang bisa dijadikan sebagai bahan pembelajaran di sekolah dasar. Begitu banyak cerita rakyat yang terdapat di Riau, terutama di Indragiri. Akan tetapi, tidak semua cerita rakyat tersebut yang bisa dijadikan sebagai bahan pembelajaran bahasa dan sastra. Oleh sebab itu, guru harus bisa memilih dan memilah cerita rakyat yang tepat dan cocok untuk diberikan kepada anak didik. Yakni cerita rakyat yang bisa dijadikan sebagai contoh dan teladan bagi anak-anak.

Pada umumnya cerita rakyat, mengandung pesan dan hikmah yang bisa diambil dan dipetik pelajarannya. Beberapa contoh cerita rakyat di atas, bisa dijadikan 
sebagai alternatif bahan pembelajaran sastra di sekolah dasar pada materi pelajaran bahasa Indonesia. Selain materi cerita yang memang tepat dan cocok untuk anak-anak usia 7-12 tahun, cerita rakyat yang dibahas di atas juga memiliki tokoh yang bisa dijadikan contoh untuk diteladani maupun untuk tidak diteladani (karena memiliki sikap yang tidak baik).

Melalui cerita rakyat yang diberikan tersebut, guru bisa mendiskusikan dengan siswa, sikap baik apa saja yang bisa dicontoh dan diteladani, dan sikap tidak baik apa saja yang tidak boleh ditiru dan harus dihindari. Dengan pemberian cerita rakyat yang bisa dijadikan contoh dan teladan ini, diharapkan guru bisa membentuk karakter baik pada diri anak didik. Pembentukan karakter melalui cerita rakyat tentu akan lebih menarik karena anak tidak akan menyadari jika guru sedang menanamkan nilai-nilai dan norma-norma kebaikan untuk diri mereka. Karakter baik dalam kedua cerita rakyat di atas adalah karakter relegius, bertanggung jawab, mandiri, kerja keras, menghargai, santun, dan kasih sayang.

Oleh sebab itu, cerita rakyat "Asal Mula Nyamuk Takut kepada Asap," dan "Si Bungsu" bisa menjadi salah satu alternatif penanaman nilai-nilai baik kepada anak dalam upaya membentuk karakter anak didik. Selain itu, pemberian materi cerita rakyat kepada anak juga dapat menjadi salah satu bentuk dan upaya pelestarian sastra lisan daerah. Sehingga sejak dini, anak-anak telah mulai mengenal sastra lisan di daerahnya.

\section{DAFTAR PUSTAKA}

Gufron, A. (2010). Integrasi Nilai-Nilai Karakter Bangsa pada Kegiatan Pembelajaran. Jurnal Ilmiah Pendidikan, Cakrawala Pendidikan, XXIX(Mei), 13-14.

Hermansyah. (2014). Sastra Lisan: Kumpulan Cerita Rakyat Indragiri
Hilir. Indragiri Hilir: Dinas Pendidikan Nasional Indragiri Hilir.

Muntihanah. (2016). Cerita Ebhi dan Khandei sebagai Bahan Bacaan Anak. Metasastra, 9(1), 67-81.

Normawati. (2014). Penentuan Cerita Rakyat Sentani, Jayapura, Kasuari dan Burung Pipit sebagai Bahan Bacaan Siswa SD. Metasastra, 7(2), 201-214.

Nurgiyantoro, B. (2013). Teori Pengkajian Fiksi. Yogyakarta: Gadjah Mada University Press.

Pusposari, D. (2015). Dongeng Jawa sebagai Pembentuk Karakter Anak. Jurnal Ilmiah Pengajaran Bahasa Dan Sastra, 11(Juni), 19-30.

Ratna, N. K. (2012). Teori, Metode, dan Teknik Penelitian Sastra. Yogyakarta: Pustaka Pelajar.

Sehandi, Y. (2016). Mengenal 25 Teori Sastra. Yogyakarta: Penerbit Ombak.

Semi, A. (2012). Metode Penelitian Sastra. Bandung: Angkasa.

Suaka, I. N. (2014). Analisis Sastra: Teori dan Aplikasi. Yogyakarta: Penerbit Ombak.

Sugihastuti. (2016). Sastra Anak. Yogyakarta: Penerbit Ombak.

Taum, Y. Y. (2011). Studi Sastra Lisan: Sejarah, Teori, Metode, dan Pendekata Disertai Contoh Penerapannya. Yogyakarta: Penerbit Lamalera. 